\title{
EVALUASI IN VITRO-IN VIVO FILM TRANDERMAL DILTIAZEM HCL DENGAN PENINGKAT PENETRASI PEG 400 SEBAGAI ANTIHIPERTENSI
}

\author{
Yulias Ninik Windriyati $^{\left.{ }^{*}\right)}$, Risha Fillah Fithria ${ }^{2)}$, Fitria Dwi Kurniawati ${ }^{1)}$, Ulfa \\ Risalatul Mukaromah ${ }^{1)}$
}

\author{
${ }^{1)}$ Bagian Farmasetika, Fakultas Farmasi Universitas Wahid Hasyim \\ ${ }^{2)}$ Bagian Farmakologi dan Farmasi Klinik, Fakultas Farmasi Universitas Wahid Hasyim \\ Jl. Menoreh Tengah X/22 Semarang 50236 Sampangan Semarang \\ *E-mail:yninik@unwahas.ac.id
}

\begin{abstract}
INTISARI
Diltiazem $\mathrm{HCl}$ merupakan antihipertensi yang setelah pemberian oral, bioavailabilitasnya hanya $40 \%$ sehingga dikembangkan lewat rute transdermal. Film transdermal tipe matriks dibuat menggunakan kombinasi polimer polivinil alkohol dan etil selulosa serta peningkat penetrasi PEG 400. Evaluasi in vitro dan in vivo dilakukan untuk mengetahui efektivitas film transdermal diltiazem $\mathrm{HCl}$ sebagai antihipertensi. Film transdermal dievaluasi karakter fisikokimia berupa keragaman bobot, ketebalan, ketahanan terhadap pelipatan dan penyerapan lembab serta kandungan zat aktif. Studi permeasi in vitro film transdermal dilakukan menggunakan membran semipermeabel dalam sel difusi Franz. Evaluasi efektivitas sebagai antihipertensi in vivo dilakukan pada tikus jantan galur Wistar yang diinduksi $\mathrm{NaCl}$ dengan metode CODA non invasive blood pressure. Hasil penelitian menunjukkan tidak ada perbedaan signifikan pada karakter fisikokimia film transdermal. Uji permeasi in vitro menunjukkan peningkatan nilai fluks seiring peningkatan kadar PEG 400 sebagai peningkat penetrasi. Evaluasi in vivo menunjukkan film transdermal diltiazem $\mathrm{HCl}$ efektif menurunkan tekanan darah diastolik dan sistolik tikus hipertensi yang diinduksi $\mathrm{NaCl}$ dalam waktu satu jam setelah pemberian film. Diltiazem $\mathrm{HCl}$ dapat berpenetrasi melalui kulit dan terabsorpsi ke dalam darah sehingga efektif sebagai antihipertensi lewat rute trasndermal.
\end{abstract}

Kata kunci: antihipertensi, diltiazem $\mathrm{HCl}$, film transdermal, PEG 400

\section{ABSTRACT}

Diltiazem HCL is an antihypertensive that low oral bioavailability of $40 \%$, so developed to transdermal preparations. A matrix type of transdermal patch of diltiazem $\mathrm{HCl}$ was prepared using polyvinyl alcohol and ethyl cellulose with PEG 400 as penetration enhancer. In vitro-in vivo evaluation were conducted to asses drug permeation through the skin and determine the effectiveness of transdermal film as an antihypertensive drug. Transdermal patches of diltiazem $\mathrm{HCl}$ were evaluated for physicochemical characteristics weight variation, thickness, folding endurance, moisture uptake, and drug content. In vitro permeation study was conducted using commercial semi permeable membrane in Franz diffusion cell. In vivo activity study was evaluated on male rat Wistar that induced $\mathrm{NaCl}$ with CODA non-invasive blood pressure method. Transdermal patches of diltiazem $\mathrm{HCl}$ were found no significant differences in terms of physicochemical characteristics. The in vitro skin permeation profiles showed increased flux values with the increase of PEG 400 as a penetration enhancer. The in vivo evaluation showed a reduction in systolic and diastolic blood pressure within one hour after the drug administration. 
Diltiazem $\mathrm{HCl}$ was able penetration into skin, absorbed in blood circulation and effective as antihypertensive via transdermal route.

Keywords : antihypertension, diltiazem HCl, PEG 400, transdermal patch

* Corresponding author:

Yulias Ninik Windriyati

Fakultas Farmasi Universitas Wahid Hasyim

Jl. Menoreh Tengah X/22 Sampangan Semarang

E-mail: yninik@unwahas.ac.id

\section{PENDAHULUAN}

Diltiazem $\mathrm{HCl}$ adalah calcium channel blocker yang secara luas digunakan untuk menstabilkan angina pektoris, mengendalikan hipertensi sistemik, dan penyakit kardiovaskular lainnya. Setelah pemberian oral, diltiazem $\mathrm{HCl}$ mengalami metabolisme lintas pertama di hepar yang cukup ekstensif sehingga bioavailabilitas absolutnya hanya $40 \%$ dengan variasi individual yang sangat besar (Moffat dkk., 2005). Bobot molekul diltiazem HCl 450,98 (Depkes RI, 1995) dan waktu paruh eliminasinya 3-5 jam (Sweetman, 2009), sehingga dibuat film transdermal untuk menghindari metabolisme lintas pertama di hepar dan memungkinkan ketersediaan hayati obat yang lebih besar.

Berbagai penelitian formulasi film transdermal diltiazem $\mathrm{HCl}$ telah dilakukan antara lain menggunakan polimer etil selulosa (EC) dan polivinil pirolidon (PVP) pada rasio 8:2 (Rao dan Diwan, 1998), kombinasi hidroksi propil metil selulosa (HPMC) dan EC juga pada perbandingan 8:2 (Limpongsa dan Umprayn, 2008), dan film transdermal dengan penggunaan polivinil alkohol (PVA) yang memberikan profil pelepasan obat secara in vitro dan permeasi kulit secara ex vivo yang baik (Patel dkk., 2010). Film transdermal dengan kombinasi polimer PVA dan EC (5:5) dan (7:3) dengan peningkat penetrasi PEG 400 memberikan karakteristik film yang baik dan dapat menghantarkan diltiazem $\mathrm{HCl}$ melewati membran semipermeabel yang menggambarkan kulit (Windriyati dkk., 2016). Penelitian ini bertujuan untuk mengevaluasi efektivitas film transdermal diltiazem $\mathrm{HCl}$ dengan kombinasi polimer PVA dan EC dan peningkat penetrasi PEG 400 sebagai antihipertensi, baik secara in vitro maupun in vivo pada tikus jantan galur Wistar yang diinduksi $\mathrm{NaCl}$.

\section{METODE PENELITIAN \\ Bahan dan Alat}

\section{Bahan}

Diltiazem HCl (Shijiazhuang Aopharm, China), PEG 400, PVA, EC, propilen glikol, etanol, $\mathrm{NaCl}, \mathrm{NaOH}, \mathrm{KH}_{2} \mathrm{PO}_{4}$ (E.Merck), aquadest, hewan uji (Tikus jantan galur Wistar usia 2-3 bulan dengan berat badan 200-250 gram yang dibeli dari Ambarawa)

\section{Alat}

Sel difusi Franz, membran semipermeabel $0,45 \mu \mathrm{m}$ (Sartorius), spektrofotometer UV (Shimadzu uv-vis), neraca analitik (OHAUS AR 3130), pipet mikro 1-1000 $\mu \mathrm{L}$ (Socorex), pH meter (Hanna Inst), alat gelas, CODA non invasive blood pressure (Kent-Scientific), spuit oral tumpul $5 \mathrm{ml}$.

\section{Jalannya Penelitian \\ Pembuatan film transdermal diltiazem HCl}

Film transdermal diltiazem $\mathrm{HCl}$ dengan peningkat penetrasi PEG 400 dibuat dengan metode solvent casting sebanyak enam formula seperti tercantum pada Tabel I. 
Tabel I. Komposisi formula film transdermal diltiazem HCl (Windriyati et al, 2016)

\begin{tabular}{lcccccc}
\multicolumn{1}{c}{ Bahan } & F1 & F2 & F3 & F4 & F5 & F6 \\
\hline Diltiazem HCl (mg) & 25 & 25 & 25 & 25 & 25 & 25 \\
PVA (mg) & 50 & 50 & 50 & 70 & 70 & 70 \\
EC (mg) & 50 & 50 & 50 & 30 & 30 & 30 \\
PEG 400 (ml) & 15 & 20 & 25 & 15 & 20 & 25 \\
Propilenglikol (ml) & 25 & 20 & 15 & 25 & 20 & 15 \\
$\quad$ Etanol 70\% (ml) & 5 & $\mathbf{5}$ & $\mathbf{5}$ & $\mathbf{5}$ & $\mathbf{5}$ & $\mathbf{5}$ \\
\hline
\end{tabular}

Sejumlah diltiazem $\mathrm{HCl}$ yang telah ditimbang dilarutkan dalam akuades. Polimer EC dilarutkan dalam etanol kemudian bersama dengan PVA didispersikan dalam akuades dengan bantuan pengaduk magnetik, dan dicampur dengan bahan lainnya. Setelah terbentuk campuran homogen, didiamkan pada suhu ruang untuk menghilangkan gelembung udara baru dituang ke dalam wadah tahan panas dan dikeringkan pada $50^{\circ} \mathrm{C}$ dalam oven hingga terbentuk film yang fleksibel. Film dikeluarkan dari wadah dan dipotong-potong dengan ukuran tertentu sesuai perhitungan dosis. Tiap film mengandung $25 \mathrm{mg}$ diltiazem $\mathrm{HCl}$, dikemas dalam aluminium foil dan disimpan dalam desikator hingga pengujian dilakukan.

\section{Uji kandungan zat aktif}

Sejumlah 5 lembar film yang diambil secara acak dari masing-masing formula dipotongpotong, dimasukkan ke dalam $200 \mathrm{~mL}$ dapar fosfat $\mathrm{pH}$ 7,4 dan diaduk menggunakan pengaduk magnetik selama 30 menit. Larutan dimasukkan ke dalam labu takar dan volume dicukupkan hingga $250 \mathrm{~mL}$. Sampel larutan dianalisis secara spektrofotometri UV pada panjang gelombang maksimal, kemudian dihitung kadar diltiazem $\mathrm{HCl}$ terlarut menggunakan kurva kalibrasi yang telah dibuat sebelumnya. Kandungan diltiazem $\mathrm{HCl}$ dalam tiap film diperhitungkan berdasarkan bobot rata-rata film. Pengujian kandungan zat aktif dilakukan triplo hingga diperoleh kandungan rata-rata dan standar deviasi (SD).

\section{Uji permeasi kulit secara in vitro}

Uji permeasi secara in vitro menggunakan alat Franz diffusion cell dengan membran kulit tiruan berupa membran semipermeabel $0,45 \mu \mathrm{m}$ komersial yang telah direndam dalam larutan isopropyl miristat selama 30 menit. Kompartemen aseptor berupa larutan $\mathrm{NaCl}$ 0,9\% sedangkan kompartemen donor berupa larutan dapar fosfat $\mathrm{pH} 7,4$. Suhu dalam kompartemen dipertahankan $32 \pm 0,5{ }^{\circ} \mathrm{C}$. Volume sampel diambil dari kompartemen aseptor pada interval waktu tertentu dan diganti sejumlah volume yang diambil dengan cairan medium yang baru. Sampel disaring dengan membran filter $0,45 \mu \mathrm{m}$, dan dianalisis kadarnya dengan spektrofotometri pada panjang gelombang $236 \mathrm{~nm}$ (Dhiman dkk., 2011).

\section{Uji aktivitas antihipertensi}

Hewan uji yang digunakan sejumlah 45 ekor dibagi menjadi 9 kelompok sebagai berikut:

I : kelompok normal, hanya diberikan air minum biasa,

II : kelompok kontrol hipertensi,

III : kelompok kontrol negatif, diberikan film placebo setelah diinduksi $\mathrm{NaCl}$

IV-IX : kelompok uji, diberikan film transdermal formula I-VI setelah diinduksi $\mathrm{NaCl}$.

Sebelum prosedur dilakukan, tikus terlebih dahulu diaklimatisasi selama satu minggu. Masingmasing tikus pada kelompok II hingga IX diinduksi dengan larutan $\mathrm{NaCl} 3 \mathrm{~g} / \mathrm{KgBB}$ selama 2 minggu. Waktu awal memulai prosedur untuk tiap kelompok dibedakan dan berselang 1 hari. Tikus ditimbang berat badannya sebelum dan setelah diinduksi dengan $\mathrm{NaCl}$ (Iswandana, 2012).

Film transdermal diltiazem HCL dipotong sesuai dengan berat badan masing-masing tikus, untuk tikus dengan berat badan 200 gram menerima film dengan ukuran $0,7 \times 0,7 \mathrm{~cm}$ sesuai dengan perhitungan konversi dosis. Sebelum diberi perlakuan, terlebih dahulu diukur tekanan darah masing-masing tikus meliputi tekanan darah sistolik dan tekanan darah diastolik. Selanjutnya tikus dianestesi menggunakan uap klotoform hingga pingsan dan dicukur bulunya pada bagian abdomen hingga tersisa lapisan kulit permukaan, kemudian ditempelkan film transdermal diltiazem HCL pada bagian kulit yang telah dicukur tersebut dan direkatkan dengan plester. Setelah 1 jam diukur 
tekanan darahnya dan dibandingkan antara sebelum dan setelah perlakuan (Iswandana, 2012). Selain tekanan darah juga dilakukan pengamatan untuk denyut jantung tikus setelah diberikan film transdermal diltiazem HCL.

Penurunan tekanan darah dihitung untuk masing-masing tikus dan dihitung rata-ratanya pada tiap kelompok. Penurunan tekanan darah dapat dihitung dengan rumus:

$$
\text { Penurunan TD }=T D S, T D D a-T D S, T D D b
$$

Keterangan :

TDS, TDDa : Tekanan darah sistolik dan diastolic sebelum perlakuan

TDS, TDDb : Tekanan darah sistolik dan diastolik sesudah perlakuan

\section{Analisis Data}

Efektivitas penurunan tekanan darah dihitung antara rata-rata penurunan tekanan darah masing-masing kelompok perlakuan dengan kelompok kontrol negatif. Suatu zat uji dikatakan efektif sebagai antihipertensi jika mampu menurunkan tekanan darah sistolik $\geq 20 \mathrm{mmHg}$ (Thompson, 1990).

\section{HASIL DAN PEMBAHASAN}

Enam formula film transdermal diltiazem $\mathrm{HCl}$ dengan kombinasi polimer PVA dan EC dan peningkat penetrasi PEG 400 menghasilkan karakter film yang bobotnya seragam (simpangan baku relatif kurang dari 6\%), cukup kuat dan elastis, serta mampu mengabsorpsi lembab sebagaimana film yang dihasilkan Windriyati dkk. 2016. Kandungan zat aktif film transdermal dapat dilihat pada tabel II. Tiap formula film memenuhi ketentuan kandungan zat aktif dalam Farmakope Indonesia IV yaitu dalam rentang 85-115\% (Depkes RI, 1995). Hal ini menunjukkan bahwa pada proses pembuatan film transdermal, zat aktif diltiazem HCL telah terdistribusi rata atau homogen.

Tabel II. Kandungan zat aktif film transdermal diltiazem $\mathrm{HCl}$ dengan peningkat penetrasi PEG 400

\begin{tabular}{cc}
\hline Formula & Kandungan zat aktif $(\%) \pm$ SD \\
\hline F1 & $103,8 \pm 0,01$ \\
F2 & $98,2 \pm 0,08$ \\
F3 & $90,5 \pm 0,11$ \\
F4 & $105 \% \pm 0,36$ \\
F5 & $86 \% \pm 0,04$ \\
F6 & $100 \% \pm 0,22$ \\
\hline
\end{tabular}
gambar 1.

Hasil uji permeasi in vitro menggunakan membran sintetis selama 6 jam dapat dilihat pada

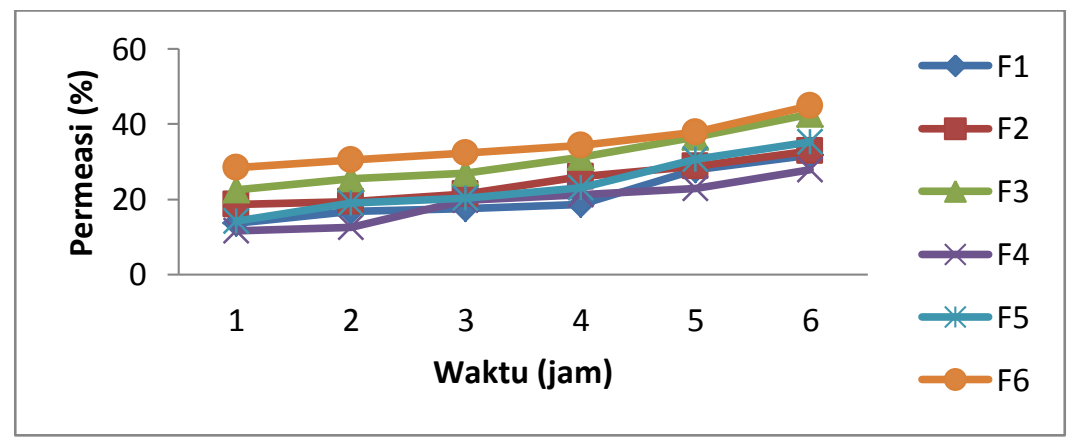

Gambar 1. Hasil uji permeasi selama 6 jam $(n=3)$ film transdermal diltiazem $\mathrm{HCl}$ dengan peningkat penetrasi PEG 400 
Terdapat peningkatan jumlah obat yang berpenetrasi melewati membran seiring dengan peningkatan jumlah PEG 400 sebagai peningkat penetrasi. Hal ini merupakan gambaran efektivitas PEG 400 sebagai peningkat penetrasi. Tidak ada perbedaan yang signifikan pada jumlah obat yang berpenetrasi dari keenam formula film dengan jumlah peningkat penetrasi yang sama.

Hasil evaluasi in vivo enam formula film sebagai antihipertensi dapat dilihat pada gambar 2 dan 3. Tekanan darah hewan uji yang diukur sebelum dan satu jam setelah pemberian film adalah tekanan darah diastolik (Gambar 2) dan sistolik (Gambar 3).

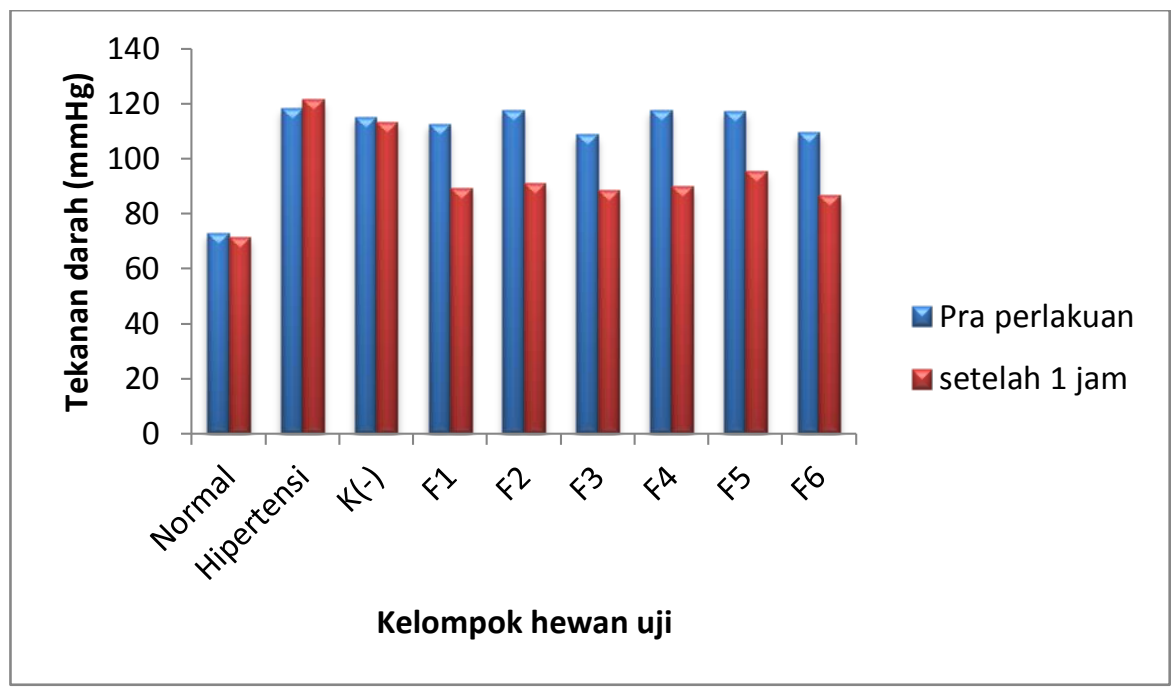

\section{Gambar 2. Rata-rata tekanan darah diastolik tikus pada setiap kelompok perlakuan sebelum dan 1 jam setelah pemberian film transdermal diltiazem $\mathbf{H C l}$.}

Berdasarkan hasil pengujian, tikus kelompok uji yang diberikan film transdermal dengan peningkat penetrasi PEG 400 (F1-F6) menunjukkan persentase penurunan tekanan darah diastolik hingga $20 \%$ yaitu rata-rata $23,8 \mathrm{mmHg}$. Data ini berbeda bermakna dengan hasil pengukuran tekanan darah diastolik yang diperoleh dari kelompok kontrol negatif maupun kelompok hipertensi. Kedua kelompok ini tidak menunjukkan penurunan tekanan darah.

Data tekanan darah sistolik dari semua kelompok hewan uji yang diamati sebelum dan dan satu jam setelah pemberian film transdermal tampak pada Gambar 3. Kelompok hewan uji yang diberikan film transdermal dengan peningkat penetrasi PEG 400 (F1-F6) menunjukkan persentase penurunan tekanan darah sistolik sebesar $15 \%(24,16 \mathrm{mmHg})$. Nilai ini tidak sebesar persentase yang ditunjukkan pada tekanan darah diastolik. Namun demikian penurunan ini berbeda bermakna dengan hasil pengukuran tekanan darah sistolik yang diperoleh dari kelompok kontrol negatif maupun kelompok hipertensi. Menurut Thompson (1990), suatu zat uji dikatakan mempunyai efek antihipertensi jika mampu menurunkan tekanan darah sistolik dan diastolik $\geq 20$ $\mathrm{mmHg}$.

Tidak ada perbedaan yang bermakna pada besarnya penurunan tekanan darah baik diastolik maupun sistolik antara kelompok hewan uji yang diberikan film F1-F6. Pemberian film transdermal diltiazem HCL dengan peningkat penetrasi PEG 400 efektif dalam menurunkan tekanan darah tetapi perbedaan konsentrasi peningkat penetrasi PEG 400 tidak memberikan perbedaan efektivitas penurunan tekanan darah yang bermakna. PEG 400 merupakan peningkat penetrasi yang meningkatkan permeabilitas dan absorpsi obat ke stratum corneum (Rao dan Diwan, 1998). Adanya bahan peningkat penetrasi seperti dapat mendorong penetrasi diltiazem $\mathrm{HCl}$ melalui stratum corneum dan mencapai pembuluh darah perifer di jaringan kulit sehingga ketersediaan hayatinya meningkat dan efektif digunakan sebagai antihipertensi. Perbedaan konsentrasi PEG 400 yang digunakan dalam penelitian ini tidak memberikan pengaruh dalam peningkatan permeabilitas dan absorpsi obat. 


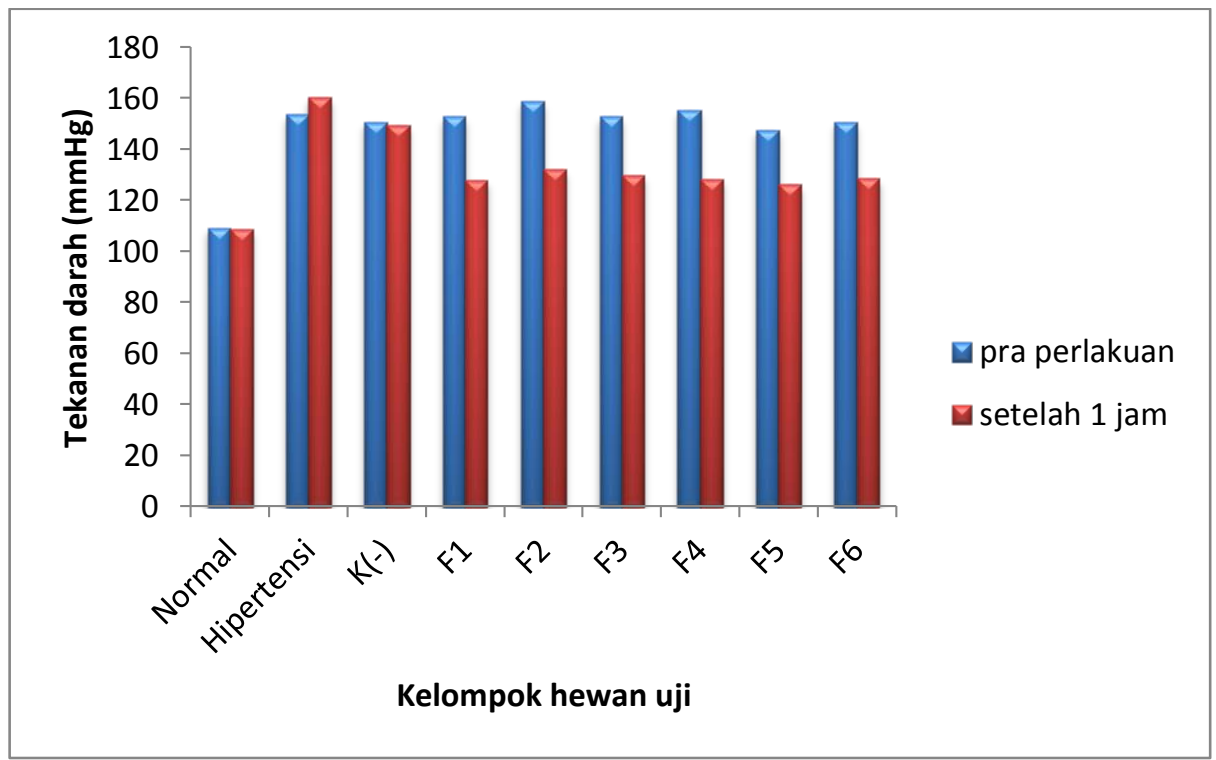

\section{Gambar 3. Rata-rata tekanan darah sistolik tikus pada setiap kelompok perlakuan sebelum dan 1 jam setelah pemberian film transdermal diltiazem $\mathrm{HCl}$.}

Film transdermal diltiazem $\mathrm{HCl}$ dapat melepaskan dan menghantarkan zat aktifnya menuju sirkulasi sistemik melewati jaringan kulit dan nyata memberikan efeknya dalam waktu 1 jam setelah pemberian. Film transdermal plasebo yang tidak mengandung zat aktif diltiazem $\mathrm{HCl}$ tidak dapat menurunkan tekanan darah. Penurunan tekanan darah hewan uji disebabkan oleh adanya diltiazem $\mathrm{HCl}$ dalam film transdermal.

Diltiazem hidroklorida merupakan antihipertensi golongan calcium channel bloker yang dapat berpengaruh terhadap denyut jantung. Pada penelitian ini denyut jantung hewan uji sebelum dan setelah pemberian film transdermal juga diukur menggunakan alat yang sama. Data denyut jantung dapat dilihat pada Gambar 4.

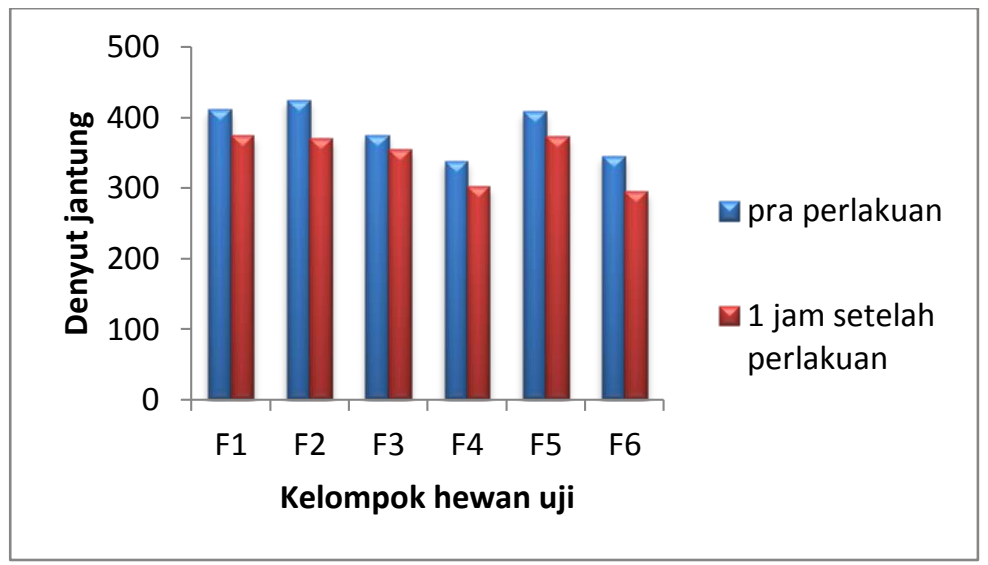

Gambar 4. Rata-rata denyut jantung tikus pada setiap kelompok perlakuan sebelum dan 1 jam setelah pemberian film transdermal diltiazem HCl.

Selain menurunkan tekanan darah, efek diltiazem $\mathrm{HCl}$ terhadap sistem kardiovaskular adalah menurunkan denyut jantung, kontraktilitas miokard dan menurunkan resistensi total melalui vasodilatasi (Shorr dkk., 2007). Hasil penelitian menunjukkan bahwa semua perlakuan pemberian film transdermal F1-F6 menyebabkan terjadinya penurunan denyut jantung. Penurunan denyut jantung ini biasanya bertahan hingga 3 jam setelah pemberian obat. 


\section{KESIMPULAN}

Penggunaan PEG 400 sebagai peningkat penetrasi dalam film transdermal dengan kombinasi polimer PVA dan EC dapat menghantarkan diltiazem $\mathrm{HCl}$ melewati stratum korneum dan meningkatkan penetrasi obat melewati kulit. Film transdermal diltiazem HCl dengan PEG 400 sebagai peningkat penetrasi dapat menurunkan tekanan darah diastolik dan sistolik hewan uji dan efektif sebagai antihipertensi.

\section{UCAPAN TERIMA KASIH}

Ucapan terima kasih ditujukan kepada Kementerian Riset Teknologi dan Pendidikan Tinggi atas bantuan dana hibah skema Penelitian Produk Terapan tahun 2016.

\section{DAFTAR PUSTAKA}

Departemen Kesehatan Republik Indonesia, 1995, Farmakope Indonesia, Edisi IV, 107- 108, 187.

Iswandana, R., 2012, Preparasi nanogel verapamil hidroklorida menggunakan metode gelasi ionik antara kitosan-natrium tripolifosfat sebagai sediaan antihipertensi, Tesis, Universitas Indonesia, Jakarta.

Limpongsa, E. dan Umprayn, K., 2008, Preparation and evaluation of diltiazem hydrochloride diffusion-controlled transdermal drug delivery system, AAPS PharmSciTech, 9(2), 464-470.

Moffat, A. C., Osselton, M. D., dan Widdop, B. (2005). Clarke's analysis of drugs and poisons. London: The Pharmaceutical Press.

Patel, N. B., Sonpal, R. N., Mohan, S., dan Selvaraj, S., 2010, Formulation and evaluation of iontophoretic transdermal delivery of diltiazem hydrochloride, International Journal of Research in Pharmaceutical Sciences .

Rao, P.R. dan Diwan, P.V., 1998, Formulation and in vitro evaluation of polymeric film of diltiazem hydrochloride and indomethacin for transdermal administration, Drug Development and Industrial Pharmacy, 24(4), 327-336.

Shorr, R.I., 2007, Drug for the Geriatric Patient. Philadelphia: Saunders Elsevier Inc.

Sweetman, S.C., (Ed), 2009, Martindale: The Complete Drug Reference, $36^{\text {th }} \mathrm{Ed}$, London Pharmaceutical Press.

Thompson, E.B., 1990, Drug Bioscreening: Drug Evaluation Techniques in Pharmacology, VCH Publ, New York, 93, 109.

Windriyati, Y.N., Sholikhah, A., dan Muliawati, F., 2016, Pengembangan film transdermal diltiazem $\mathrm{HCl}$ tipe matriks dengan kombinasi polimer polivinil alkohol dan etil selulosa serta peningkat penetrasi PEG 400, Jurnal Ilmu Farmasi dan Farmasi Klinik, 13(1), 21-26. 